\title{
Chemical Extractors to Assess Potassium Availability in Glauconitic Siltstone
}

\author{
Eliana Paula Fernandes Brasil ${ }^{1}$, Wilson Mozena Leandro ${ }^{1}$, Welldy Gonçalves Teixeira ${ }^{1}$, Marcos Antônio Vieira ${ }^{2}$, \\ José Patrício Nunes de Souza ${ }^{2} \&$ Henrique Victor Vieira ${ }^{2}$ \\ ${ }^{1}$ Soil Sector, Federal University of Goiás, Goiânia, Goiás, Brazil \\ ${ }^{2}$ Victor Vieira Consultoria Agronômica, Paraúna, Goiás, Brazil \\ Correspondence: Eliana Paula Fernandes Brasil, Campus Samambaia, Agronomy School, Federal University of \\ Goiás, Goiânia, Goiás, Brazil. E-mail: elianafernandesufg@gmail.com; elianafernandes@ufg.br
}

Received: March 31, 2020

Accepted: July 12, $2020 \quad$ Online Published: August 15, 2020

doi:10.5539/jas.v12n9p166

URL: https://doi.org/10.5539/jas.v12n9p166

\begin{abstract}
This paper aimed to evaluate the efficiency of chemical extractors to measure the availability of potassium $(\mathrm{K})$ in glauconitic siltstone. An experiment with successive crops of beans and maize was installed under field conditions in Quirinópolis, Goiás State, Brazil, in a typical ortic Neossolo Quartzarênico. For both crops, the experimental design was a randomized block with four replications, resulting in a total of 24 experimental plots. Two sources and four doses of $\mathrm{K}_{2} \mathrm{O}$ were used, in addition to a control treatment with any $\mathrm{K}$ fertilization. The sources used were glauconitic siltstone and potassium chloride $(\mathrm{KCl})$, and the doses applied through glauconitic siltstone corresponded to 1, 2, 4 and 8 times the dose of $\mathrm{K}_{2} \mathrm{O}$ applied via $\mathrm{KCl}$ as a reference. The following extractors were used: neutral ammonium citrate (NAC), citric acid $2 \%(\mathrm{CA}), \mathrm{CA}+$ ammonium fluoride $0.5 \%\left(\mathrm{NH}_{4} \mathrm{~F}\right)$, tartaric acid $5 \%(\mathrm{TA})+$ sodium fluoride $0.5 \%(\mathrm{NaF})(1: 100), \mathrm{TA}+\mathrm{NaF} 0.5 \%(1: 500)$, hydrochloric acid $(\mathrm{HCl})$, and the method for extracting potassium from silicatic materials (MAPA-8.2.4.2). Among the tested extractors, the best one regarding productivity was the MAPA-8.2.4.2. The NAC and CA extractors showed the lowest correlations and should not be used henceforth to quantify soluble $\mathrm{K}$ from glauconitic siltstone.
\end{abstract}

Keywords: potassium sources, glauconite, chemical extractors, plant nutrition

\section{Introduction}

Potassium chloride $(\mathrm{KCl})$ is the main source of potassium $(\mathrm{K})$ used worldwide, representing more than $95 \%$ of potassium fertilizers consumed (ANDA, 2016). Brazil is the world's second-largest K importer, behind China, and the third largest $\mathrm{K}$ products consumer, which represents $15 \%$ of the market worldwide. However, about $90 \%$ of the $\mathrm{K}$ consumed in the country is imported, mainly from Canada and Russia, which account for more than $60 \%$ of the world's K supply (Quaresma, 2009).

Because $\mathrm{KCl}$ contains about $63 \% \mathrm{~K}_{2} \mathrm{O}$, this fertilizer is economically competitive and has a good efficiency compared to other $\mathrm{K}$ sources (Martins et al., 2008). However, the low national production capacity of $\mathrm{KCl}$ (Brazil currently exploits one single $\mathrm{K}$ deposit) along with the high demand from agriculture makes the country vulnerable and extremely dependent on the import of $\mathrm{K}$ fertilizers. This scenario harms the Brazilian trade balance, thus justifying the need for research into other unconventional sources of K (Nicolini, 2009).

One unconventional source of K is glauconitic siltstone, a sedimentary rock founded in São Gotardo, located in Minas Gerais State, Brazil. This rock is about $70 \mathrm{~m}$ thick and is highly homogeneous in texture, mineralogy, and $\mathrm{K}$ distribution. It is mostly composed of glauconite mineral (40-80\%), K-feldspar (10-15\%), quartz (10-60\%), and muscovite (5\%) (Moreira et al., 2016). Glauconitic siltstone is a promising $\mathrm{K}$ fertilizer, with about $10 \% \mathrm{~K}_{2} \mathrm{O}$ (Violatti et al., 2019). The production process for glauconitic siltstone fertilizers is based on mechanical activation technology (Singla et al., 2019). This process requires size reduction, screening, and classification.

The advancement of studies on the use of new K sources with low solubility in water and high agronomic efficiency has highlighted the need for investigating new methods of $\mathrm{K}$ analysis in soluble forms. Several studies have shown positive responses with alternative sources of K to improve soil fertility, yield, and quality of plants, such as the ones using glauconite as a K source for crops including coffee (Dias et al., 2018) and sunflower 
(Torqueti et al., 2018). Therefore, this paper seeks to identify the most suitable extractor to characterize the availability of $\mathrm{K}$ in soils fertilized with glauconitic siltstone.

\section{Method}

\subsection{Site Selection and Soil Characterization}

A field experiment was conducted in Quirinópolis, Goiás state, Brazil, in a successive crop system with common bean (Phaseolus vulgaris L.) and maize (Zea mays L.). The soil from the experimental site was classified as Entisol according to the USDA soil taxonomy (Soil Survey Staff, 2010), which correspond to a typical ortic Neossolo Quartzarênico (RQo) according to the Brazilian System of Soil Classification (SiBCS) (Santos et al., 2013). The physical and chemical characteristics of the soil are indicated in Tables 1.

Table 1. Physical analysis and chemical analysis of the soils used in the study in Quirinópolis, Goiás State, Brazil

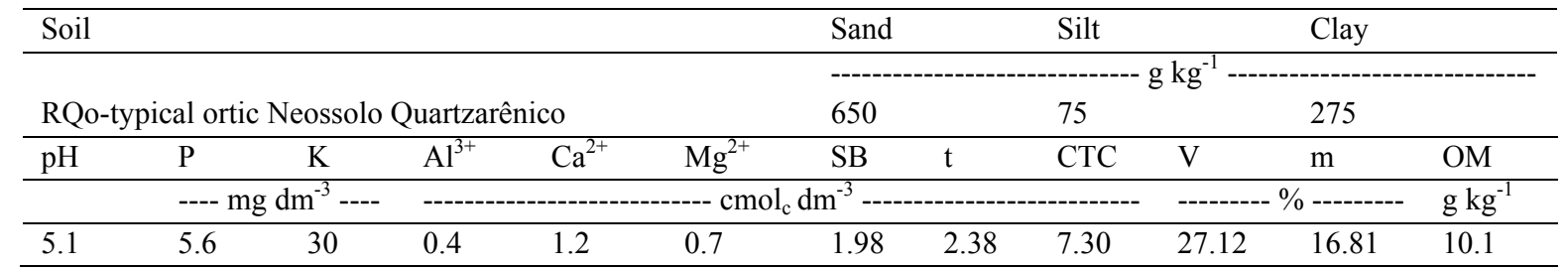

Note. Soil: Pipette Method. P. K: Mehlich-1 extractor; Al. Ca. Mg: extracted with 1.0 mol/L KCl; SB: sum of bases; t: CTC effective; CTC: cation exchange capacity at $\mathrm{pH}$ 7.0; V: base saturation; m: exchangeable acidity saturation; OM: organic matter (Walkley-Black).

\subsection{Experimental Design and Treatments}

A successive crop system was carried out with common bean (variety BRS Style) followed by maize (hybrid AS 1581 from Dow AgroSciences company). The experiment was laid out in a randomized complete block design with four replicates. The treatments consisted of two K sources, such as granular potassium chloride $(\mathrm{KCl})$ and powder glauconitic siltstone, which were applied at the standard rate of $\mathrm{K}$ recommended for common bean $(72 \mathrm{~kg}$ $\left.\mathrm{ha}^{-1} \mathrm{~K}_{2} \mathrm{O}\right)$ and maize $\left(150 \mathrm{~kg} \mathrm{ha}^{-1} \mathrm{~K}_{2} \mathrm{O}\right)$ crops. The $\mathrm{K}$ sources were characterized in terms of total $\mathrm{K}$ concentration of $\mathrm{K}_{2} \mathrm{O}$ (Table 2).

Table 2. Chemical characterization of $\mathrm{KCl}$ and glauconitic siltstone

\begin{tabular}{ll}
\hline Source & Total $\mathrm{K}_{2} \mathrm{O}(\%, \mathrm{w} / \mathrm{w})$ \\
\hline $\mathrm{KCl}$ & 60 \\
Glauconitic siltstone & 10 \\
\hline
\end{tabular}

Note. $\mathrm{KCl}$ : water; Glauconitic siltstone: method for extracting silicatic minerals (MAPA-8.2.4.2).

The experimental plot consisted of $20 \mathrm{~m}^{2}$. On the first treatment, the total rate of $\mathrm{K}_{2} \mathrm{O}$ was applied to the first crop of the growing system, and on the other three it was applied at 222,444 , and $888 \mathrm{~kg} \mathrm{ha}^{-1}$ of $\mathrm{K}_{2} \mathrm{O}$, in the form of glauconitic siltstone. The highest rate of glauconitic siltstone applied was $1,776 \mathrm{~kg} \mathrm{ha}^{-1}$ of $\mathrm{K}_{2} \mathrm{O}$ and a control treatment without $\mathrm{K}$ application was included. The treatments are described in Tables 3 and 4.

Table 3. Treatments applied to the common bean crop (first crop)

\begin{tabular}{llll}
\hline $\mathrm{N}$. & Treatment & $\mathrm{K}_{2} \mathrm{O}$ & Commercial fertilizer \\
\hline & & ------------- & $\mathrm{kg} \mathrm{ha}^{-1}------------$ \\
1 & Absolute control & 0.00 & 0.00 \\
2 & Positive control $(\mathrm{KCl})$ & 72.00 & 120.00 \\
3 & Glauconitic siltstone $1 \mathrm{x}$ & 222.00 & $2,220.00$ \\
4 & Glauconitic siltstone 2x & 444.00 & $4,440.00$ \\
5 & Glauconitic siltstone 4x & 888.00 & $8,880.00$ \\
6 & Glauconitic siltstone 8x & $1,776.00$ & $17,760.00$ \\
\hline
\end{tabular}


Table 4. Treatments applied to the maize crop (second crop)

\begin{tabular}{|c|c|c|c|}
\hline N. & Treatment & $\mathrm{K}_{2} \mathrm{O}$ & Commercial fertilizer \\
\hline & & \multicolumn{2}{|c|}{---------------------- kg ha' } \\
\hline 1 & Absolute control & 0.00 & 0.00 \\
\hline 2 & Positive control $(\mathrm{KCl})$ & 150.00 & 250.00 \\
\hline 3 & Glauconitic siltstone $1 \mathrm{x}$ & 0.00 & 0.00 \\
\hline 4 & Glauconitic siltstone $2 \mathrm{x}$ & 0.00 & 0.00 \\
\hline 5 & Glauconitic siltstone $4 \mathrm{x}$ & 0.00 & 0.00 \\
\hline 6 & Glauconitic siltstone $8 \mathrm{x}$ & 0.00 & 0.00 \\
\hline
\end{tabular}

\subsection{Field Experiment}

All K treatments were applied 30 days before sowing the common bean, incorporated into the soil and incubated. In addition, $270 \mathrm{~kg} \mathrm{ha}^{-1}$ of NP fertilizer on 7-34-00 formulation was added to the soil to supply nitrogen $(\mathrm{N})$ and phosphorus $\left(\mathrm{P}_{2} \mathrm{O}_{5}\right)$ in order to meet the crop nutrient requirements, corresponding to $18.9 \mathrm{~kg} \mathrm{ha}^{-1} \mathrm{~N}$ and $91.8 \mathrm{~kg} \mathrm{ha}^{-1}$ $\mathrm{P}_{2} \mathrm{O}_{5}$. Limestone was also added at different proportions to raise the percentage base saturation of soil to $70 \%$. Gramoxone 3.0 L ha ${ }^{-1}$ was used to desiccate the experimental area and invasive plants were controlled with specified products.

At the end of the common bean cultivation cycle, all plants were harvested, and soil samples were collected and analyzed. Before sowing the successive crop, the soil was again fertilized with $\mathrm{N}$ and $\mathrm{P}$ by applying $250 \mathrm{~kg} \mathrm{ha}^{-1}$ of 9-43-00 NP fertilizer, and a total of $250 \mathrm{~kg} \mathrm{ha}^{-1}$ of urea was applied at four different times during the experimental period to supply $\mathrm{N}$ to the crops.

The maize crop was then cultivated. Seeds were treated with Master root $\left(2.0 \mathrm{~mL} \mathrm{~kg}^{-1}\right.$ seed $)$, Maxim $\left(2.0 \mathrm{~mL} \mathrm{~kg}^{-1}\right.$ seed), Premium ( $2.0 \mathrm{ml} \mathrm{kg}^{-1}$ seed), and Fipronil $\left(2.0 \mathrm{~mL} \mathrm{~kg}^{-1}\right.$ seed). In post-emergence weed control was performed using Atrasin $\left(2.0 \mathrm{~L} \mathrm{ha}^{-1}\right)$. At early growth stage (V2), $120 \mathrm{~kg} \mathrm{ha}^{-1}$ of ammonium sulfate was applied, and at stage $\mathrm{V} 4$, foliar fertilization was carried out using Equalizes $0.75 \mathrm{~L} \mathrm{ha}^{-1}$. At the stage R1, fungicide was applied using Native $0.6 \mathrm{~L} \mathrm{ha}^{-1}$ along with Mancozeb $1.5 \mathrm{~L} \mathrm{ha}^{-1}$.

\subsection{Potassium Extractors}

A total of eight methods were tested to extract $\mathrm{K}$ from glauconitic siltstone. They are described below and can be accessed in more detail in the Brazilian manual of official analytical methods for fertilizers and correctives (MAPA, 2017).

\subsubsection{Neutral Ammonium Citrate (NAC)}

This extraction method consists of dissolving $370 \mathrm{~g}$ of pure crystallized citric acid monohydrate $\left(\mathrm{C}_{6} \mathrm{H}_{8} \mathrm{O}_{7} \cdot \mathrm{H}_{2} \mathrm{O}\right)$ in $1.5 \mathrm{~L}$ of water and adding $345 \mathrm{~mL}$ of pure ammonium hydroxide $\left(\mathrm{NH}_{4} \mathrm{OH}\right)$ containing $28-29 \% \mathrm{NH}_{3} . \mathrm{If} \mathrm{NH}_{3}$ concentration is less than $28 \%$, add additional volume to compensate for the lower concentration and decrease the volume of water in which the citric acid will be dissolved. Allow the mixture to cool and then measure the $\mathrm{pH}$. If needed, adjust the $\mathrm{pH}$ to $7.0 \pm 0.05$ with solutions of aqueous ammonium hydroxide solution $(1+7)$ and citric acid $10 \% \mathrm{w} / \mathrm{v}$, or use more concentrated solutions of both reagents. Store the solution in a tightly closed bottle. Check the $\mathrm{pH}$ weekly, adjusting it when needed.

\subsubsection{2\% Citric Acid Solution}

This extraction method consists of preparing a citric acid solution $20 \mathrm{~g} \mathrm{~L}^{-1}$ as follows: weigh $10 \mathrm{~g}$ of pure crystallized citric acid monohydrate $\left(\mathrm{C}_{6} \mathrm{H}_{8} \mathrm{O}_{7} . \mathrm{H}_{2} \mathrm{O}\right)$ and dissolve in water, transfer to a $500 \mathrm{~mL}$ volumetric flask, and complete the volume. Use the freshly prepared extractor.

\subsubsection{2\% Citric Acid Solution + 0.5\% Ammonium Fluoride}

The methodology consists of preparing a citric acid solution with $20 \mathrm{~g} \mathrm{~L}^{-1}$ and ammonium fluoride $5 \mathrm{~g} \mathrm{~L}^{-1}$ as follows: weigh $10 \mathrm{~g}$ of pure crystallized citric acid monohydrate $\left(\mathrm{C}_{6} \mathrm{H}_{8} \mathrm{O}_{7} . \mathrm{H}_{2} \mathrm{O}\right)$ and $2.5 \mathrm{~g}$ of ammonium fluoride, dissolve in water, transfer to a $500 \mathrm{~mL}$ volumetric flask, and complete the volume. Use it freshly prepared.

\subsubsection{5\% Tartaric Acid Solution}

This extraction method consists of preparing a solution of tartaric acid with $50 \mathrm{~g} \mathrm{~L}^{-1}$ as follows: weigh $25 \mathrm{~g}$ of pure tartaric acid, dissolve in water, transfer to a $500 \mathrm{~mL}$ volumetric flask, and complete the volume. Use the freshly prepared extractor. 


\subsubsection{5\% Tartaric Acid Solution + 0.5\% Sodium Fluoride}

This extraction method consists of preparing a solution of tartaric acid with $50 \mathrm{~g} \mathrm{~L}^{-1}$ and sodium fluoride $5 \mathrm{~g} \mathrm{~L}^{-1}$ as follows: weigh $25 \mathrm{~g}$ of pure tartaric acid and $2.5 \mathrm{~g}$ of pure sodium fluoride, dissolve in water, transfer to a $500 \mathrm{ml}$ flask volumetric, and complete the volume with water. Use the freshly prepared extractor.

\subsubsection{Hydrochloric Acid $(\mathrm{HCl})$}

This extraction method consists of weighing 0.5-2.5 $\mathrm{g}$ of the $\mathrm{K}$ source with an accuracy of $0.1 \mathrm{mg}$. Transfer the sample to a $150 \mathrm{~mL}$ beaker and add $10 \mathrm{~mL}$ of concentrated $\mathrm{HCl}$. Cover the beaker with a watch glass and bring it to a moderate boil on a hot plate until dry, without letting the residue burn. For samples with contents above 5\% by mass or less soluble raw materials, this step must be repeated with a new addition of concentrated $\mathrm{HCl}$, heating again until close to dryness. Prepare a blank test in parallel. Add $20 \mathrm{~mL}$ of the aqueous $\mathrm{HCl}$ solution $(1+5)$ to the residue, boil slightly for $10 \mathrm{~min}$, allow it to cool and transfer to a $100 \mathrm{~mL}$ volumetric flask. Complete the volume with water and mix. Filter on medium or fine pore filter paper, if needed, collecting the filtrate in a dry container.

\subsubsection{Method for Extracting Silicatic Minerals (MAPA-8.2.4.2)}

This method is indicated for samples which contains fritted trace elements (FTEs) and another silicatic materials, insoluble in water (MAPA, 2017). This extraction method consists of weighing 0.5 to $1.0 \mathrm{~g}$ of the K source, with a precision of $0.1 \mathrm{mg}$, transferring it to a platinum crucible and adding $5 \mathrm{~mL}$ of $\mathrm{HClO}_{4}$ and $5 \mathrm{~mL}$ of concentrated $\mathrm{HF}$. Prepare a blank test in parallel. Place the crucible in a flat-bottomed porcelain dish and set on a hot plate. Heat until dense white $\mathrm{HClO}_{4}$ vapors are released. Remove from the plate, allow to cool and transfer to a $150 \mathrm{~mL}$ beaker, adding water to a volume of about $50 \mathrm{~mL}$. Heat until moderate boil for $10 \mathrm{~min}$. Allow it to cool. Transfer to a 100 $\mathrm{mL}$ volumetric flask. Complete the volume with water and mix. Filter on medium or fine pore filter paper, if needed, receiving the filtrate in a dry container. If intermediate dilutions are needed to adjust the Ca concentration to the reading interval, use $\mathrm{HCl}$ solution $(1+23)$, adding to the last dilution an adequate volume of the lanthanum solution, so that the reading solution contains $1 \%$ lanthanum $\mathrm{w} / \mathrm{v}\left(10 \mathrm{mg} \mathrm{L}^{-1} \mathrm{La}\right)$.

\subsubsection{Hot Plate Extraction (1:100 and 1:500)}

This extraction method consists of weighing $0.5 \mathrm{~g}$ (1:100 ratio) and $0.1 \mathrm{~g}$ (1: 500 ratio) of the K source, quarter it with a smaller mesh size of 50 mesh and place it in a $100 \mathrm{~mL}$ beaker. Then, add $50 \mathrm{~mL}$ of the extraction solution to the container (to maintain a 1:100 or 1:500 ratio) and place it on the hot plate to heat to $95{ }^{\circ} \mathrm{C}$. Keep this temperature for $15 \mathrm{~min}$, without boiling. After heating, allow the solution to cool and transfer to a $100 \mathrm{~mL}$ volumetric flask, washing the beaker with small portions of distilled water until the volume is completed. Remove a $2 \mathrm{~mL}$ aliquot for $50 \mathrm{~mL}$ cup and add $18 \mathrm{~mL}$ of distilled water (10x dilution). For the $\mathrm{K}$ source, a new dilution of 10x was performed so that the readings would occur within the photometer curve.

\subsection{Treatment Measurements}

At the end of each cultivation cycle, all plants were harvested, and soil samples were collected using a hand auger, and analyzed.

For determining the levels of soluble $\mathrm{K}$ contained in the glauconitic siltstone, all samples were quartered (Jones riffles) until the final sample had the appropriate weight (about $250 \mathrm{~g}$ ). The glauconitic siltstone was then crushed and sieved through a 100 -mesh sieve to obtain the appropriate particle size $(<0.147 \mathrm{~mm})$. Afterward, samples of glauconitic siltstone were submitted to chemical analyses by all eight extraction methods. For all methods, the concentration of $\mathrm{K}$ was determined by flame emission spectrophotometry. The concentration of total $\mathrm{K}_{2} \mathrm{O}$ contained in the glauconitic siltstone solubilized by the extractor (Total $\mathrm{Ks}$, $\mathrm{kg} \mathrm{ha}^{-1}$ ) were obtained by multiplying the rate of total $\mathrm{K}_{2} \mathrm{O}$ applied by the average concentration $\mathrm{K}_{2} \mathrm{O}$ extracted from each method, as follows:

$$
\text { Total } \mathrm{Ks}=\frac{\mathrm{K}_{2} \times \mathrm{K}_{1}}{10}
$$

\subsection{Statistical Analysis}

The different $\mathrm{K}$ concentration were subjected to analysis of variance by the $\mathrm{F}$ test, and the averages were compared by the Duncan test at $5 \%$ probability.

To evaluate the efficiency of each extractor, simple linear regression equations were adjusted to estimate the $\mathrm{K}$ levels recovered by the extractors and the plants as a function of the $\mathrm{K}$ rates applied via glauconitic siltstone.

Also, Pearson's correlation analyses were performed between the K concentration recovered by the extractors and the plants as a function of the $\mathrm{K}$ rates applied via glauconitic siltstone. 


\section{Results and Discussion}

Data of common bean production showed that the $4 \mathrm{x}$ and $8 \mathrm{x}$ glauconitic siltstone were better than all other treatments the $1 \mathrm{x}$ and $2 \mathrm{x}$ glauconitic were statistically equivalent to positive control $(\mathrm{KCl})$. For maize production, with glauconitic siltstone $2 \mathrm{x}, 4 \mathrm{x}$ and $8 \mathrm{x}$, the highest yields were obtained; production of $1 \mathrm{x}$ glauconitic siltstone did not differ statistically from both absolute control and positive control $(\mathrm{KCl})$ (Table 6). The results emphasize both the efficiency of glauconitic siltstone, and at the same time, the importance of the appropriate rate to be applied.

Table 6. Yield of common bean and maize crops as a function of different sources and rates of $\mathrm{K}_{2} \mathrm{O}$

\begin{tabular}{|c|c|c|c|c|}
\hline Treatments & $\mathrm{K}_{2} \mathrm{O}$ & Common bean & Maize & Accumulated \\
\hline & \multicolumn{4}{|c|}{ 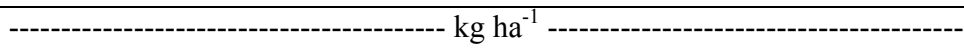 } \\
\hline Absolute control & 0.00 & $2,824.50 \mathrm{c}$ & $6,994.00 \mathrm{~b}$ & $9,818.50$ \\
\hline Positive control $(\mathrm{KCl})$ & 222.00 & $2,983.50 \mathrm{bc}$ & $7,286.00 \mathrm{~b}$ & $10,269.50$ \\
\hline Glauconitic siltstone $1 \mathrm{x}$ & 222.00 & $3,035.25 \mathrm{bc}$ & $7,192.00 \mathrm{~b}$ & $10,227.25$ \\
\hline Glauconitic siltstone $2 \mathrm{x}$ & 444.00 & $3,017.25 \mathrm{bc}$ & $7,488.00 \mathrm{ab}$ & $10,505.25$ \\
\hline Glauconitic siltstone $4 \mathrm{x}$ & 888.00 & $3,573.00 \mathrm{a}$ & $7,439.00 \mathrm{ab}$ & $11,012.00$ \\
\hline Glauconitic siltstone $8 \mathrm{x}$ & $1,776.00$ & $3,233.25 \mathrm{~b}$ & $7,854.00 \mathrm{a}$ & $11,087.25$ \\
\hline
\end{tabular}

Note. The means followed by the same letters in columns are not significantly different by Duncan's test $(\mathrm{p} \leq 0.05)$.

A simple linear correlation was built with these results and the accumulated yield of common bean and maize crops (Table 7). Figure 1 contains data related to the total level of $\mathrm{K}_{2} \mathrm{O}$ contained in the extraction solution $\left(\mathrm{kg} \mathrm{ha}^{-1}\right)$ and accumulate yield of beans and maize crops.

The best correlation between extracted $\mathrm{K}$ and accumulated yield was obtained using the MAPA-8.2.4.2 $(\mathrm{r}=$ 0.76945), revealing that it is the most appropriate method for extracting total levels of $\mathrm{K}_{2} \mathrm{O}$ in soils fertilized with glauconitic siltstone.

Both MAPA-8.2.4.2 and tartaric acid 5\% $+0.5 \% \mathrm{NaF}(1: 500(\mathrm{r}=0.76725)$ extractors greatly exceeded the others when correlated to the accumulated yield of common bean and maize crops. Further, they showed correlation coefficients values very close to each other.

The correlations between accumulated yield with K extracted by either neutral ammonium citrate $(r=-0.03655)$ or citric acid $2 \%(r=-0.03353)$ were the lowest. However, the use of fluorides (citric acid $2 \%+\mathrm{NH}_{4} \mathrm{~F} 0.5 \%$ ) promoted a slight correlation increase $(\mathrm{r}=0.42948)$, which increased a bit more when using tartaric acid $5 \%+\mathrm{NaF}$ $0.5 \%$ at the ratios of $1: 100(\mathrm{r}=0.63214)$ and $1: 500(\mathrm{r}=0.76725)$. The increasing availability of $\mathrm{K}$ induced by fluorides reveals that $\mathrm{K}$ could be released from these sources over time in a slow-release.

The $\mathrm{TA}+\mathrm{NaF} 0.5 \%(1: 100), \mathrm{HCl}, \mathrm{NAC}, \mathrm{CA}$, and $\mathrm{CA}+\mathrm{NH}_{4} \mathrm{~F}$ extractors presented a very poor correlation with an accumulated yield of the crops, indicating that they should not be used in the measurement of total $\mathrm{K}_{2} \mathrm{O}$.

Table 7. Pearson's correlation coefficients and probability between different extractors used in glauconitic siltstone and the accumulated productivity of common bean and maize

\begin{tabular}{lll}
\hline Variable & Pearson correlation coefficients $(\mathrm{r}), \mathrm{n}=24$ & Probability \\
\hline $\mathrm{NAC}^{1}$ & -0.03655 & 0.8654 \\
$\mathrm{CA}^{2}$ & -0.03353 & 0.8764 \\
$\mathrm{CA}+\mathrm{NH}_{4} \mathrm{~F}^{3}$ & 0.42948 & 0.0362 \\
$\mathrm{TA}^{4}+\mathrm{NaF}^{5}(1: 100)$ & 0.63214 & 0.0009 \\
$\mathrm{TA}+\mathrm{NaF}(1: 500)$ & 0.76725 & $<0.0001$ \\
$\mathrm{HCl}$ & 0.57318 & 0.0034 \\
$\mathrm{MAPA}-8.2 .4 .2^{7}$ & 0.76945 & $<0.0001$ \\
\hline
\end{tabular}

Note. ${ }^{1}$ NAC: neutral ammonium citrate; ${ }^{2} \mathrm{CA}: 2 \%$ citric acid $;{ }^{3} \mathrm{NH}_{4} \mathrm{~F}: 0.5 \%$ ammonium fluoride $;{ }^{4} \mathrm{TA}: 5 \%$ tartaric acid; ${ }^{5} \mathrm{NaF}$ : $0.5 \%$ sodium fluoride; ${ }^{6} \mathrm{HCl}$ : hydrochloric acid; ${ }^{7}$ Method for extracting silicatic minerals (MAPA-8.2.4.2). 
CNA

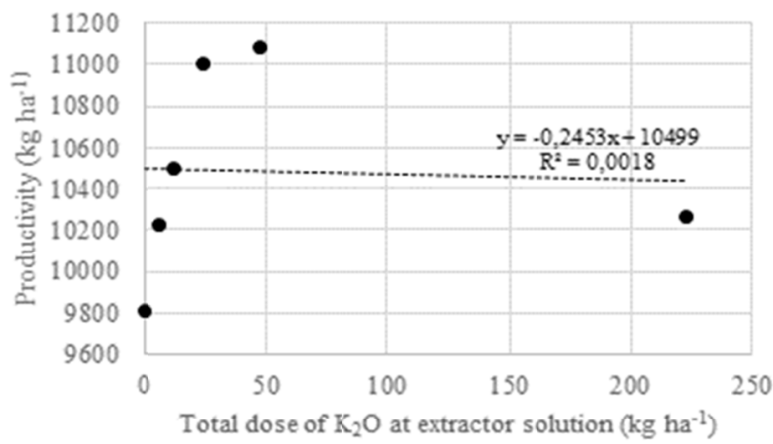

Citric Acid 2\%

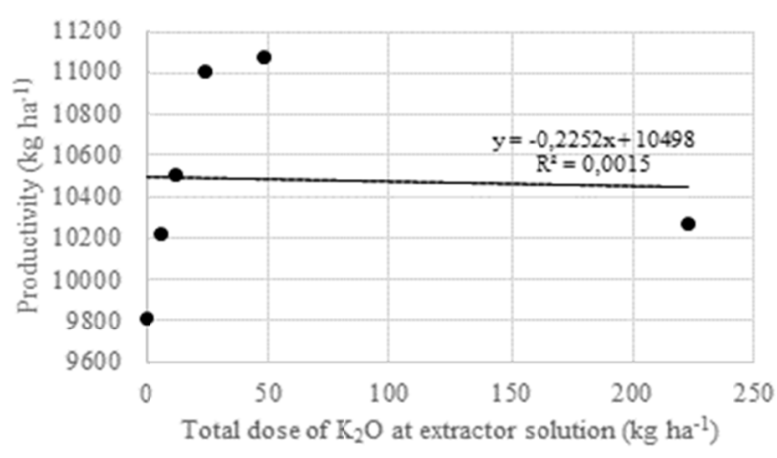

Citric Acid $2 \%+0,5 \% \mathrm{NH}_{4} \mathrm{~F}$

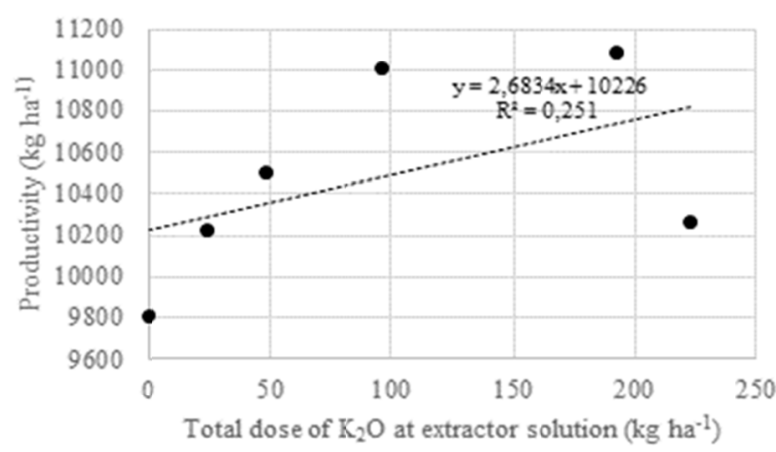

Method for extracting silicatic minerals (MAPA-8.2.4.2)

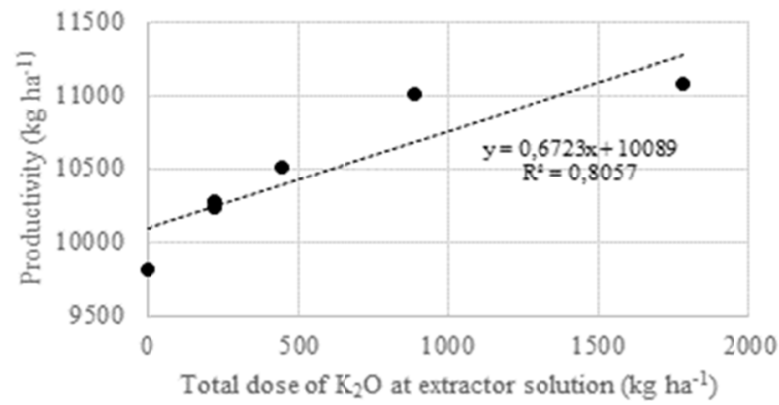

Tartaric Acid 5\%+0,5\% NaF (1:100)

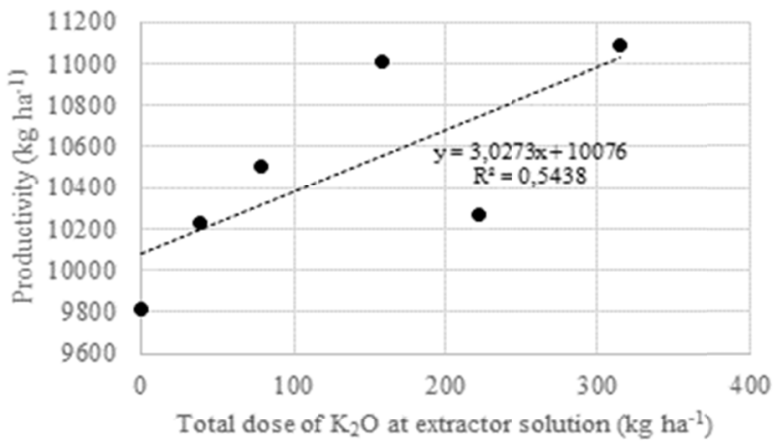

Tartaric Acid 5\%+0,5\% NaF (1:500)

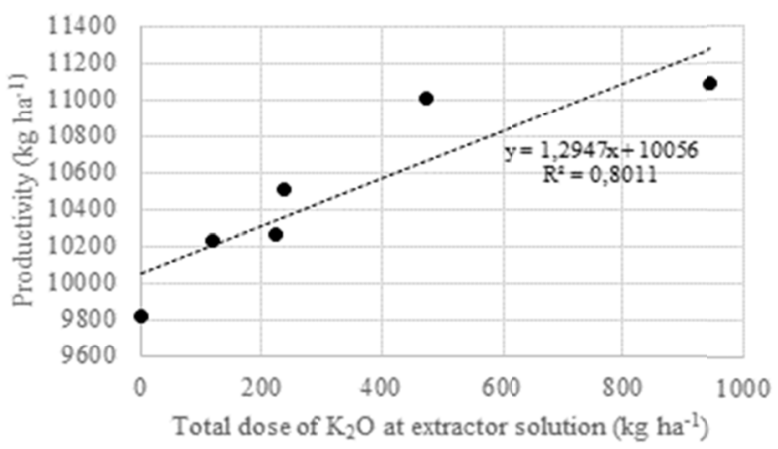

$\mathrm{HCl}$

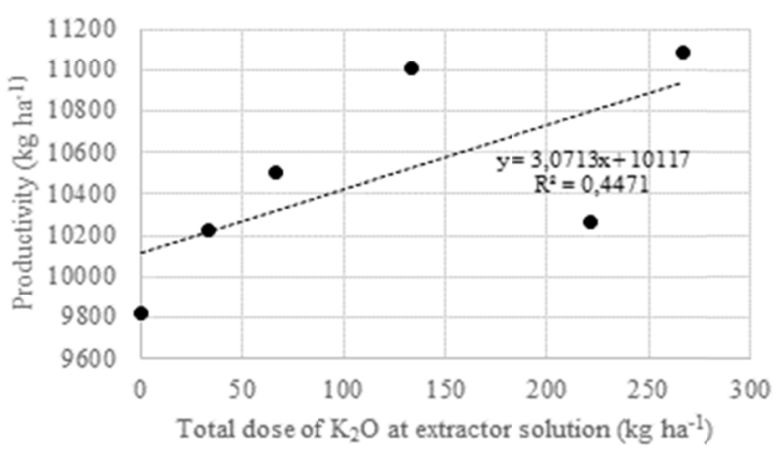

Figure 1. Total $\mathrm{K}_{2} \mathrm{O}$ concentration contained in the extraction solution $\left(\mathrm{kg} \mathrm{ha}^{-1}\right)$ and accumulates the yield of beans and maize crops 


\section{Conclusions}

The results show that method for extracting silicatic minerals (MAPA-8.2.4.2) provided the best correlation between soluble $\mathrm{K}$ and accumulated yield of common bean and maize crops, demonstrating the high agronomic efficiency of glauconitic siltstone.

The extractors tartaric acid 5\% $\mathrm{NaF} 0.5 \%$ (1:100), $\mathrm{HCl}$, NAC, citric acid $2 \%$, and citric acid $2 \%+\mathrm{NH}_{4} \mathrm{~F} 0.5 \%$ (1:100) presented correlation coefficients values close to zero and, therefore, should not be used to quantify soluble K from glauconitic siltstone.

\section{References}

ANDA (Associação Nacional para Difusão de Adubos). (2016). Anuário estatístico do setor de fertilizantes. São Paulo, Brazil. Retrieved from http://anda.org.br/arquivos

Dias, K. G.L., Guimarães, P. T. G., Carmo, D. L., Reis, T. H. P. R., \& Lacerda, J. J. J. (2018). Alternative sources of potassium in coffee plants for better soil fertility, productivity, and beverage quality. Pesquisa Agropecuária Brasileira, 53(12), 1355-1362. https://doi.org/10.1590/s0100-204x2018001200008

Korndörfer, G. H., Pereira, H. S., \& Nolla, A. (2004). Análise de silício: solo, planta e fertilizante. Uberlândia, MG: Instituto de Ciências Agrárias, Universidade Federal de Uberlândia. Retrieved from https://www.researchgate.net/publication/312454775_Analise_de_silicio_solo_planta_e_fertilizante

MAPA (Ministério da Agricultura, Pecuária e Abastecimento). (2017). Manual de Métodos Analíticos Oficiais para Fertilizantes e Corretivos (p. 230). MAPA, Brasília.

Martins, E. S., Oliveira, C. G, Resende, A. V., \& Matos, M. S. F. (2008). Agrominerais-Rochas silicáticas como fontes minerais alternativas de potássio para a agricultura. In A. B. Luz, \& F. A. F. Lins (Eds.), Rochas e minerais industriais no Brasil: Usos e especificações (2nd ed., p. 9). Rio de Janeiro: CETEM/MCT.

Nicolini, K. P. (2009). Produção de fertilizantes de liberação lenta a partir da torta de mamona (Ricinuscomunis) $e$ de uréia intercalada em caulins (Doctorate's thesis, Univerisdade Federal do Paraná, Programa de Pós-Graduação em Química, Setor de Ciências Exatas, Curitiba, Paraná, Brazil).

Quaresma, L. F. (2009). Desenvolvimento de estudos para elaboração do plano duodecenal (2010-2030) de geologia, mineração e transformação mineral. Brasília: Ministério de Minas e Energia, Secretaria de Geologia, Mineração e Transformação Mineral. Retrieved from http://www.mme.gov.br/sgm/galerias/ arquivos/plano_duo_decenal/a_mineracao_brasileira/P19_RT28_Perfil_do_Ouro.pdf

Santos, H. G., Jacomine P. K. T., Anjos, L. H. C., Oliveira, V. A., Lumbreras, J. F., Coelho, M. R., ... Oliveira, J. B. (2013). Sistema Brasileiro de Classificação de Solos (3rd ed.). Brasília: Embrapa.

Singla, R., Alex, T. C., \& Kumar, R. (2019). On mechanical activation of glauconite: physicochemical changes, alterations in cation exchange capacity and mechanisms, Powder Technology, 360(15). https://doi.org/ 10.1016/j.powtec.2019.10.035

Soil Survey Staff. (2010). Keys to Soil Taxonomy (11th ed.). USDA, National Resources Conservation Service, National Soil Survey Center, Lincoln, NE.

Torqueti, S. T. S., Boldrin, K. V. F., Nascimento, A. M. P., Paiva, P. D. O., Furtini Neto, A. E., \& Luz, I. C. A. (2016). Fonte alternativa de potássio no cultivo do girassol ornamental. Ciência e Agrotecnologia, 40(3), 257-264. ttps://doi.org/10.1590/1413-70542016403036115

Violatti, I. C. A., Gualberto, C. A. C., Silveira, L. H., Santos, G. A., Ferreira, B. C., Machado, P. M. M., \& Pereira, H. S. (2019). Glauconitic siltstone as multi-nutrient fertilizer for Urochloa brizantha cv. Marandú. Australian Journal of Crop Science, 13(8), 1280-1287. https://doi.org/10.21475/ajcs. 19.13.08.p1609

Wadt, P. G. S. (2011). Diagnose foliar e recomendação de adubação para lavouras comerciais (p. 69). EMBRAPA, Rio Branco.

\section{Copyrights}

Copyright for this article is retained by the author(s), with first publication rights granted to the journal.

This is an open-access article distributed under the terms and conditions of the Creative Commons Attribution license (http://creativecommons.org/licenses/by/4.0/). 